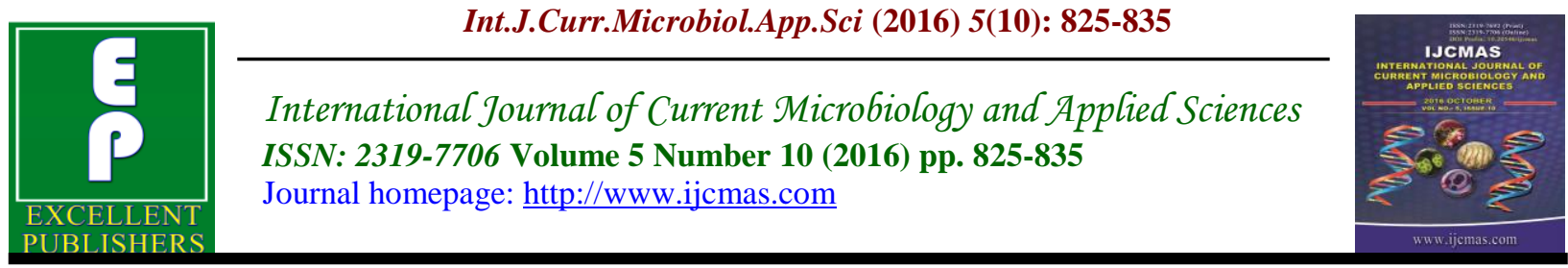

Original Research Article

http://dx.doi.org/10.20546/ijcmas.2016.510.090

\title{
The Potential Use of NPK and Bacterial Isolates to Degrade Heglig crude Oil in Sudan
}

\author{
Maha AbelHafeez Mohamed ${ }^{\text {* }}$, AwadGalal Osman², Adil Ali Elhussein ${ }^{3}$, \\ Somaya Sirelkhatim Mohamed ${ }^{4}$ and Ahmed Ali Mahdi ${ }^{5}$ \\ ${ }^{1}$ Univesity of AlNeelain, Faculty of Science and Technology, Department of \\ Environmental studies, Sudan \\ ${ }^{2}$ Environment, Natural Resource and Desertification Research Institute (NCR) Khartoum, Sudan \\ ${ }^{3}$ University of Khartoum, Faculty of Science, Dep. of Botany, Sudan \\ ${ }^{4}$ Environmental, Natural Resource and Desertification \\ Research Institute (NCR) Khartoum, Sudan \\ ${ }^{5}$ University of Khartoum, Faculty of Agriculture, Dep. of Botany, Sudan \\ *Corresponding author
}

\begin{tabular}{|c|c|}
\hline & A B S T R A C T \\
\hline Keywords & \multirow{4}{*}{$\begin{array}{l}\text { A study was carried out to examine the capabilities of three bacterial isolates to } \\
\text { degrade crude oil in NPK- supplemented soil to which crude oil was added at } 1,3,5 \\
\text { and } 10 \% .750 \mathrm{mg} \text { NPK } / 100 \mathrm{~g} \text { soil at a ratio of } 2: 1: 1 \text { was added to the polluted soil } \\
\text { and mixed thoroughly. The tested bacterial isolates revealed great potentialities for } \\
\text { the degradation of crude oil. The highest oil degradation percent } 90 \% \text { and } 77.9 \% \\
\text { were recorded for Isolate HAC in } 1 \% \text { and } 3 \% \text { oil polluted soil after } 12 \text { weeks of } \\
\text { incubation, respectively. The biodegradation percentages were upgraded to } 98.61 \% \\
\text { and } 93.11 \% \text { in } 1 \% \text { and } 3 \% \text { oil polluted and NPK supplemented soil, respectively. } \\
\text { Gas chromatographic analysis performed that Hegligcrude oil consisted of n- } \\
\text { alkanes with chain length of C12 to C35and all the tested isolates could totally } \\
\text { degrade chain hydrocarbons with } \mathrm{C} 12, \mathrm{C} 14, \mathrm{C} 33 \text { and C35 fractions. }\end{array}$} \\
\hline $\begin{array}{l}\text { Biodegradation, } \\
\text { bacterial isolates, } \\
\text { NPK, } \\
\text { GC analysis, } \\
\text { crude oil. }\end{array}$ & \\
\hline Article Info & \\
\hline $\begin{array}{l}\text { Accepted: } \\
\text { 25 September } 2016 \\
\text { Available Online: } \\
10 \text { October } 2016\end{array}$ & \\
\hline
\end{tabular}

\section{Introduction}

Soil contamination by petroleum hydrocarbons is one of the world's most common environmental problems (US EPM, 2000). Mechanical and chemical methods for remediation of hydrocarbon- polluted environment are often expensive, technologicaly complex and lack public acceptance (Vidali, 2001).Therefore, bioremediation processes become the most effective and acceptable method for removal of petroleum hydrocarbons.
However, the success of bioremediation technologies depends on biodegradation potentiality of the native populations. Usually, microbial isolates from the soil that are historically exposed to hydrocarbon pollution exhibit a higher potential of biodegradation than others with no history of such exposure (Leahy and Colwell, 1990). In addition to microorganism type, other factors that limit biodegradation include available nutrients, $\mathrm{pH}$, temperature, moisture, oxygen, soil properties, and 
contaminant concentration (Walter et al., 2005; Atlas and Bartha, 2006).

The activity of microorganisms could be greatly enhanced by biostimulation process which may involve the addition of electron acceptors, electron donors or nutrients (Nysönenetal., 2009). The effects of nutrients mainly nitrogen, phosphorus and potassium (NPK), aeration, biostimulation of indigenous soil microorganisms and inoculation of extraneous microbial consortia on the bioremediation of oil contaminated soil have been investigated (Ayotamuno et al., 2006; Sang-Hwan et al., 2007 and Yan et al., 2016)

Some reports on the influence of fertilizer application on degradation of hydrocarbons are available. For example, Lin et al. (1999) reported that fertilizer application in crude oil-contaminated soil enhanced marsh plant growth, soil microbial populations, microbial respiration rates and oil biodegradation rates. They concluded that bioremediation with fertilizer application significantly reduced total targeted linear hydrocarbon and aromatic hydrocarbon remaining in the soil, by $81 \%$ and $17 \%$, respectively, compared to those of the nonfertilized controls.

The effectiveness of fertilizers application on the bioremediation of the crude oil in subarctic intertidal sediments was also reported by Pelletier et al. (2004). However, several authors have reported the negative effects of high NPK levels on the biodegradation of hydrocarbons (Cha^neau et al., 2005) especially on aromatics (Carmichae and Pfaender, 1997).

In this work the effect of NPK on the efficiency of the bacterial isolates to degrade the crude oil in soil contaminated with Heglig crude oil was examined.

\section{Materials and Methods}

An uncontaminated soil sample was obtained from oil production site of Heglig field in southern Kordofan, Sudan. Some physical and chemical soil properties were determined according to the methods described by Ryan et al. (2001). Four sets of bottles, each containing $100 \mathrm{~g}$ soil were prepared and the humidity of the soil was adjusted to approximately $60 \%$ of the field capacity. Crude oil was added to each set to make a concentration of $1 \%, 3 \%, 5 \%$ and 10 $\% . N P K$ was then added to each bottle at a rate of $375 \mathrm{mg}, 167.5 \mathrm{mg}$ and $187.5 \mathrm{mg}$ per bottle, respectively.

Three bacterial isolates(HAC, HP and $\mathrm{HWH}$ ) of known oil-degrading potential were obtained from Environment, Natural Resources and Desertification Research Institute, National Centre for Research, Sudan. The bacterial isolates were cultured in flasks containing Mineral Salt Medium (MSM) (Kennedy et al., 1993).The flasks were incubated on a reciprocal shaker at room temperature for 10-15 days. Ten $\mathrm{ml}$ of each culture were added to each soil set. An uninoculated set of NPK supplemented oil contaminated soil was also prepared as a control. Bottles were sealed with plastic lids and fixed with rubbers. Some pores were made on the top of the covers.The bottles were then, incubated at room temperature in the dark for 12 weeks and crude oil residues were determined at two weeks intervals.

\section{Determination of the crude oil residues}

The amount of crude oil residues in the soil was determined by the weight loss method of Bossert and Bartha (1984) in which $3 \mathrm{~g}$ of soil were suspended in $10 \mathrm{ml}$ of diethyl ether in a universal bottle for oil extraction. The solvent-oil mixture was evaporated at room temperature overnight. The percentage of oil 
residues was then calculated according to Ijah and Ukpe (1992).

\section{Gas Chromatographic analysis of residual crude oil}

The analysis of crude oil residues was performed by Varina 3800 gas chromatography for saturate (alkanes) component on a FID detector under the following condition: column Sil POWA CB $(50 \mathrm{~m} \times 0.21 \mathrm{~mm})$; initial temperature $40^{\ominus} \mathrm{C}$; final temperature $290^{\circ} \mathrm{C}$; ramp rate $3^{\circ} \mathrm{C}$ per $\mathrm{min}$; carrier gas was nitrogen $(64 \mathrm{ml} / \mathrm{min})$; injection temperature $280^{\circ} \mathrm{C}$.

\section{Results and Discussion}

\section{Soil and crude oil analysis}

The physico-chemical characteristics of Heglih soil were presented in table 1 . The laboratory analysis revealed that the soil was clay, alkaline with high electrical conductivity. The nutrient contents were $0.0224 \% \mathrm{~N}, \quad 1.5 \% \mathrm{P}$ and $0.87 \mathrm{ppm} \mathrm{K}$. Analysis of Heglig crude oilis carried out by Petroleum Central Laboratory and data was presented in table 2 .

The API value of Heglig crude oil is 31.03 (Table 2). Therefore, it was classified as a medium according to the American Petroleum Institute gravity (API, 1986).

\section{Biodegradation of total petroleum hydrocarbon by the bacterial isolates}

Figures 1, 2 and 3 display the estimation of crude oil degradation by the weight loss method for the three isolates at four different concentrations and when were supplemented with NPK. All isolates were capable of degrading crude oil. As expected, the biodegradation percentages have gradually decreased with increasing concentration of crude oil. At $1 \%$ concentration, a degradation percentage of $90 \%, 70.9 \%$ and $67 \%$ have been recorded for isolate HAC, $\mathrm{HP}$ and $\mathrm{HWH}$, respectively. At 3\% oil concentration, degradation percentages of 77.9,56 and 55\% were recorded for HAC, $\mathrm{HP}$ and $\mathrm{HWH}$, respectively while at $5 \%$ oil concentration $51 \%, \quad 38.7 \%$ and $37.9 \%$ degradation were recorded for HAC, HP and $\mathrm{HWH}$, respectively.

Biodegradation of total petroleum hydrocarbon in soil supplemented with NPK

All isolates were highly efficient in degrading the crude oil in soil supplemented with NPK. The percentage of degradation ranged from $97.85 \%$ to $98.61 \%, 93.11 \%$ to $94.21 \%, 71.33 \%$ to $88.13 \%$ and from $39.50 \%$ to $40.12 \%$ for $1 \%, 3 \%, 5 \%$ and $10 \%$ crude oil respectively.

\section{Biodegradation of crude oil components}

Residual oil components in 3\% oil contaminated soil was determined before and after the incubation period(12 weeks) using GC. The result revealed 24 types of nAlkanes hydrocarbons with chain lengths of C12 to C35of the crude oil before the soil was incubated. During the 12 weeks incubation period, the tested isolates showed different ability to degrade different crude oil components. Isolate HAC had highest degradation percentage of the component fractions compared with isolates HP and HWH which had approximately the same degradation ability. However, the lowest degradation of the component fractions was recorded for the control (Fig.3 and Table 3). The result also showed that the HAC and $\mathrm{HWH}$ isolates degraded the $\mathrm{C} 33$ completely while HP recorded $12.6 \%$. In soils contaminated with $3 \%$ crude oil and supplemented with NPK fertilizer, all 
isolates exhibited highest level of the component fractions degradation (Fig.4 and Table 4) and they could degrade C12, C13, C14, C33 and C35fractions completely.

Some previous studies have shown that most potential bacteria for petroleum hydrocarbon degradation have been isolated from areas contaminated with oil (Chaerun et al., 2004, Abu Shanab et al., 2015). The present results showed clear relationships between the rate of biodegradation and concentration of oil in the contaminated soil. Higher biodegradation rates were recorded in soil contaminated with 1 and $3 \%$ oil. This could be attributed to an increase in the activity of a particular soil microbe in this oil pollution level (Zajic and Supplisson, 1972). Ijah and Antai (2003a) reported high degradation of hydrocarbons in soil contaminated with $10 \%$ and $20 \%$ crude oil compared to those contaminated with 30 and $40 \%$ crude oil within a period of 12 months. The reason for the low efficiency of oil degradation by the microbes at $5 \%$ and $10 \%$ oil concentrations might be attributed to the toxicity of the oil to the microbial flora of the soil at these high concentrations of oil (5\% and 10\%). This trend of low biodegradation due to high oil concentration has been reported by different authors (Rahman et al., 2000; Ijah and Antai, 2003b and Udgireet al., 2015).

The bacterial community of oil contaminated soil showed greater changes by the addition of inorganic compounds such as $\mathrm{P}, \mathrm{K}, \mathrm{Ca}$, and $\mathrm{Mg}$ (Evans et al., 2004). Hollender et al. (2003) and Walworth et al. (2007) reported that, the addition of inorganic or organic nitrogen is an effective approach (biostimulation) to enhance the bioremediation process. Positive effects of nitrogen amendment on microbial activity and/or petroleum hydrocarbon degradation have been widely demonstrated by various authors (Châneau et al., 2005; Margesin, et al., 2003). Microorganisms are known to attack specific compounds present in crude oil which is a complex mixture of saturates, aromatics and polar compounds (Barathi and Vasudevan, 2001). Ainon et al. (2010) reported that gas chromatography analysis showed that the South Angsi crude oil components of $\mathrm{C}_{12}$ to $\mathrm{C}_{25}$ were more extensively degraded by Actinomycits lwoffii after $24 \mathrm{~h}$ of incubation compared to other bacteria over the same period.

Table.1 Physical and chemical characteristics of Heglig soil

\begin{tabular}{|l|l|}
\hline Characters & \multicolumn{1}{|c|}{ Heglig soil } \\
\hline $\mathrm{pH}$ & 7.62 \\
\hline $\mathrm{EC}(\mathrm{ds} / \mathrm{m})$ & 0.288 \\
\hline $\mathrm{N}(\%)$ & 0.0224 \\
\hline $\mathrm{P}(\mathrm{ppm})$ & 1.5 \\
\hline O.C. $(\%)$ & 0.56 \\
\hline O.M. $(\%)$ & 0.96 \\
\hline $\mathrm{Na}(\mathrm{ppm})$ & 16.05 \\
\hline $\mathrm{K}(\mathrm{ppm})$ & 0.87 \\
\hline $\mathrm{Ca}(\mathrm{ppm})$ & 0.80 \\
\hline $\mathrm{Mg}(\mathrm{ppm})$ & 1.20 \\
\hline $\mathrm{Moisture}$ content $(\%)$ & 5.589 \\
\hline Clay $(\%)$ & 75.62 \\
\hline Silt $(\%)$ & 12.50 \\
\hline Sand $(\%)$ & 11.88 \\
\hline
\end{tabular}


Int.J.Curr.Microbiol.App.Sci (2016) 5(10): 825-835

Table.2 Characterization of Hegligcrude oil

\begin{tabular}{|l|l|}
\hline characters & Heglig crude oil \\
\hline Density $\left(\mathrm{g} / \mathrm{cm}^{3}\right)$ & 0.869 \\
\hline API (American Petroleum Institute) gravity & 31.03 \\
\hline S.G. (Significant Gravity) & 0.870 \\
\hline K (Characterization factor) & 12.4 \\
\hline Crude oil \% & 3.6 \\
\hline
\end{tabular}

Table.3 Degradation \% by soil microorganisms of 3\% crude oil component fractions after 12 weeks of incubation

\begin{tabular}{|c|c|c|c|c|}
\hline \multirow{2}{*}{$\begin{array}{l}\text { Component } \\
\text { Fraction }\end{array}$} & \multicolumn{4}{|c|}{ Degradation (\%) } \\
\hline & Control & HAC & HWH & HP \\
\hline $\mathrm{C}_{12}$ & 22.76 & 53.19 & 32.87 & 58.65 \\
\hline $\mathrm{C}_{13}$ & 12.17 & 73.43 & 48.81 & 54.00 \\
\hline $\mathrm{C}_{14}$ & 1.521 & 77.72 & 57.09 & 61.24 \\
\hline $\mathrm{C}_{15}$ & 15.96 & 82.66 & 66.85 & 72.55 \\
\hline $\mathrm{C}_{16}$ & 5.98 & 79.35 & 57.27 & 65.65 \\
\hline $\mathrm{C}_{17}$ & 7.31 & 80.75 & 58.62 & 64.66 \\
\hline $\operatorname{Pr}$ & 10.73 & 71.60 & 42.61 & 44.47 \\
\hline $\mathrm{C}_{18}$ & 24.76 & 83.16 & 64.01 & 65.28 \\
\hline $\mathrm{Ph}$ & 20.42 & 77.39 & 38.26 & 50.76 \\
\hline $\mathrm{C}_{19}$ & 34.48 & 88.18 & 72.40 & 74.08 \\
\hline $\mathrm{C}_{20}$ & 32.72 & 83.32 & 63.07 & 62.68 \\
\hline $\mathrm{C}_{21}$ & 33.07 & 85.60 & 68.06 & 62.91 \\
\hline $\mathrm{C}_{22}$ & 28.74 & 84.70 & 62.75 & 59.29 \\
\hline $\mathrm{C}_{23}$ & 15.43 & 82.76 & 53.58 & 49.05 \\
\hline $\mathrm{C}_{24}$ & 11.43 & 77.28 & 46.31 & 43.61 \\
\hline $\mathrm{C}_{25}$ & 6.34 & 78.23 & 40.21 & 38.76 \\
\hline $\mathrm{C}_{26}$ & 5.78 & 77.38 & 39.62 & 36.08 \\
\hline $\mathrm{C}_{27}$ & 5.56 & 74.44 & 35.84 & 29.33 \\
\hline $\mathrm{C}_{28}$ & 4.61 & 69.81 & 29.17 & 22.20 \\
\hline $\mathrm{C}_{29}$ & 7.28 & 64.98 & 25.05 & 15.24 \\
\hline $\mathrm{C}_{30}$ & 4.76 & 58.80 & 13.00 & 6.22 \\
\hline $\mathrm{C}_{31}$ & 23.76 & 60.17 & 24.18 & 24.18 \\
\hline $\mathrm{C}_{32}$ & 14.24 & 60.46 & 24.68 & 11.28 \\
\hline $\mathrm{C}_{33}$ & 8.79 & 60.86 & 39.25 & 16.14 \\
\hline $\mathrm{C}_{34}$ & 5.52 & 100 & 100 & 12.60 \\
\hline $\mathrm{C}_{35}$ & 19.20 & 72.83 & 65.17 & 47.77 \\
\hline
\end{tabular}


Table.4 Degradation (\%) by soil microorganismsof crude oil component fractions in the presence NPK after 12 weeks

\begin{tabular}{|l|l|l|l|l|}
\hline \multirow{2}{*}{$\begin{array}{l}\text { Component } \\
\text { Fraction }\end{array}$} & \multicolumn{4}{|c|}{ Degradation (\%) } \\
\cline { 2 - 5 } & Control & HAC+NPK & HWH+NPK & HP+NPK \\
\hline $\mathrm{C}_{12}$ & 22.76 & 100 & 100 & 100 \\
\hline $\mathrm{C}_{13}$ & 12.17 & 100 & 100 & 100 \\
\hline $\mathrm{C}_{14}$ & 1.521 & 100 & 100 & 100 \\
\hline $\mathrm{C}_{15}$ & 15.96 & 97.77 & 96.63 & 97.65 \\
\hline $\mathrm{C}_{16}$ & 5.98 & 95.53 & 93.84 & 95.43 \\
\hline $\mathrm{C}_{17}$ & 7.31 & 95.26 & 92.72 & 93.78 \\
\hline $\mathrm{Pr}$ & 10.73 & 93.42 & 91.83 & 93.37 \\
\hline $\mathrm{C}_{18}$ & 24.76 & 95.33 & 94.19 & 95.71 \\
\hline $\mathrm{Ph}$ & 20.42 & 94.30 & 94.07 & 95.38 \\
\hline $\mathrm{C}_{19}$ & 34.48 & 97.70 & 97.56 & 97.31 \\
\hline $\mathrm{C}_{20}$ & 32.72 & 96.91 & 96.73 & 97.37 \\
\hline $\mathrm{C}_{21}$ & 33.07 & 96.38 & 96.63 & 97.32 \\
\hline $\mathrm{C}_{22}$ & 28.74 & 96.20 & 96.65 & 97.27 \\
\hline $\mathrm{C}_{23}$ & 15.43 & 95.86 & 96.41 & 96.90 \\
\hline $\mathrm{C}_{24}$ & 11.43 & 95.77 & 96.43 & 96.89 \\
\hline $\mathrm{C}_{25}$ & 6.347 & 92.67 & 93.56 & 94.00 \\
\hline $\mathrm{C}_{26}$ & 5.787 & 90.78 & 91.25 & 93.33 \\
\hline $\mathrm{C}_{27}$ & 5.56 & 90.71 & 91.11 & 91.35 \\
\hline $\mathrm{C}_{28}$ & 4.61 & 89.91 & 90.58 & 90.71 \\
\hline $\mathrm{C}_{29}$ & 7.28 & 89.82 & 89.73 & 90.05 \\
\hline $\mathrm{C}_{30}$ & 4.76 & 82.34 & 82.43 & 83.62 \\
\hline $\mathrm{C}_{31}$ & 23.76 & 77.43 & 77.70 & 78.64 \\
\hline $\mathrm{C}_{32}$ & 14.24 & 88.14 & 85.25 & 87.40 \\
\hline $\mathrm{C}_{33}$ & 8.79 & 100 & 100 & 100 \\
\hline $\mathrm{C}_{34}$ & 5.52 & 71.34 & 53.33 & 52.943 \\
\hline $\mathrm{C}_{35}$ & 19.20 & 100 & 100 & 100 \\
\hline & & & & \\
\hline
\end{tabular}

Fig.1 Degradation \%of crude oilby HAC isolate and HAC+NPK during 12 weeks period

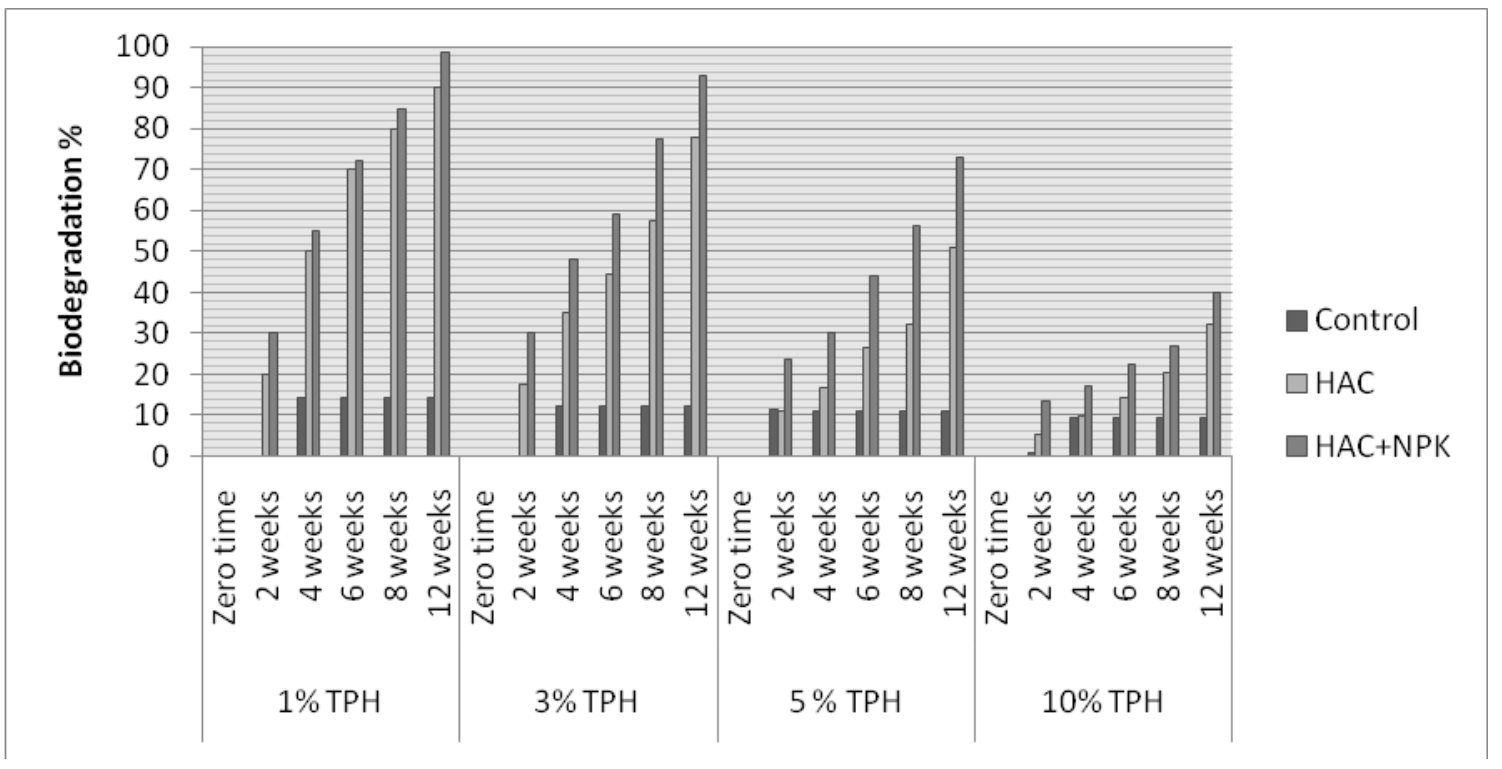


Fig.2 Degradation \% of crude oil by HP isolate and HP+NPK during 12 weeks period

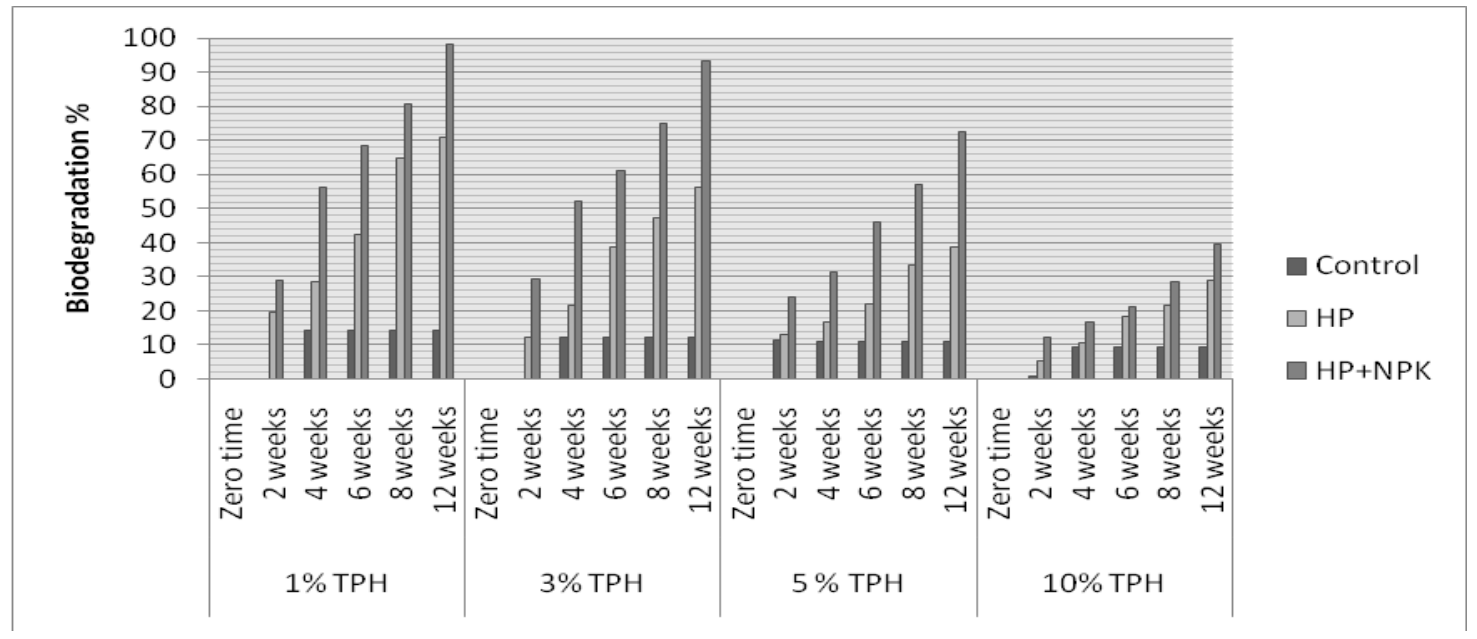

Fig.3 Degradation \% of crude oil by HWH isolate and HWH+NPK during 12 weeks period

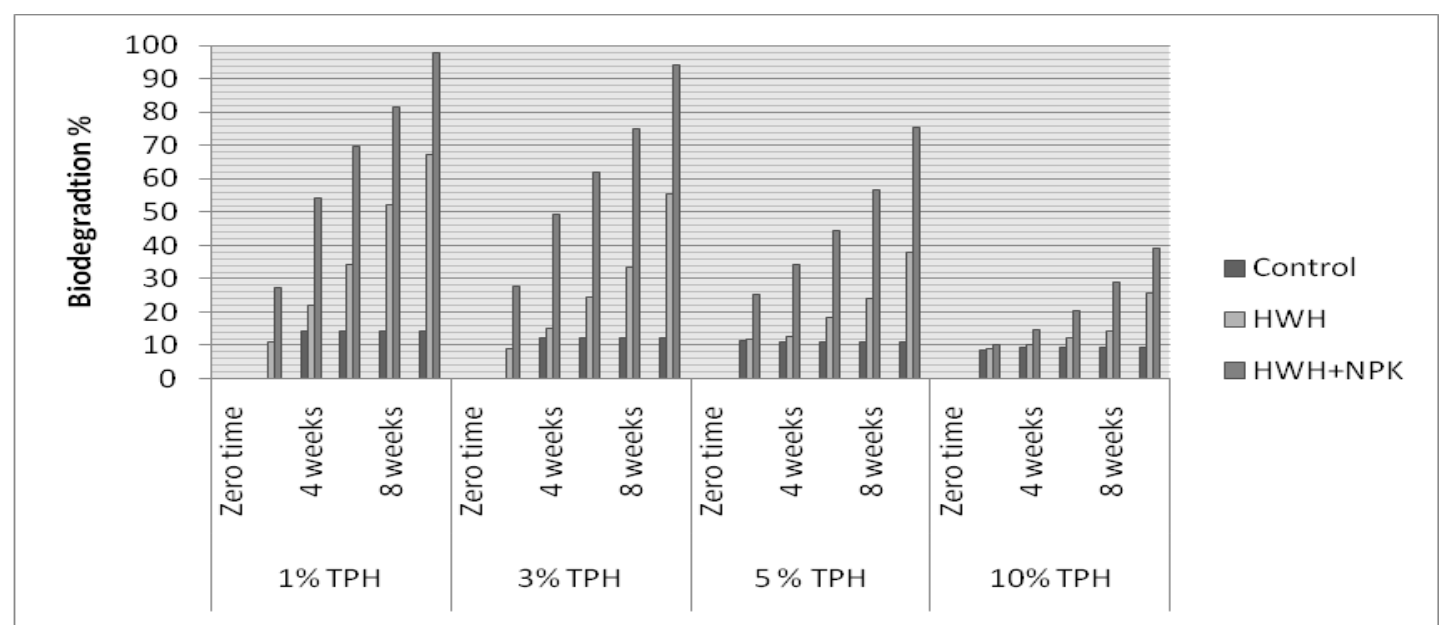

Fig.4 Chromatogram of TPH degradation in control (A), HP (B), HAC (C), and HWH (D) of Heglig crude oil after 3 month

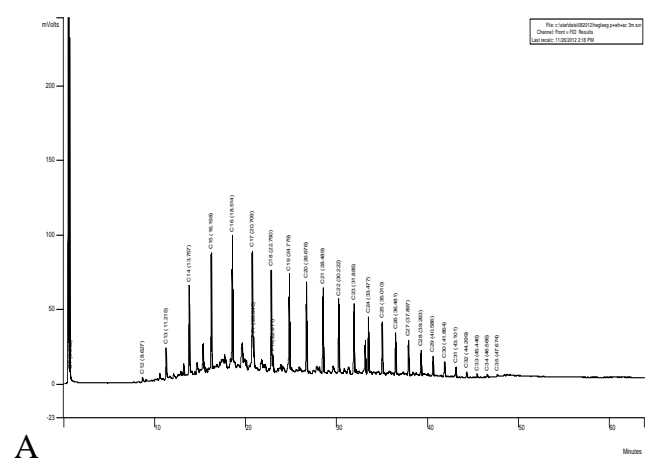


Int.J.Curr.Microbiol.App.Sci (2016) 5(10): 825-835

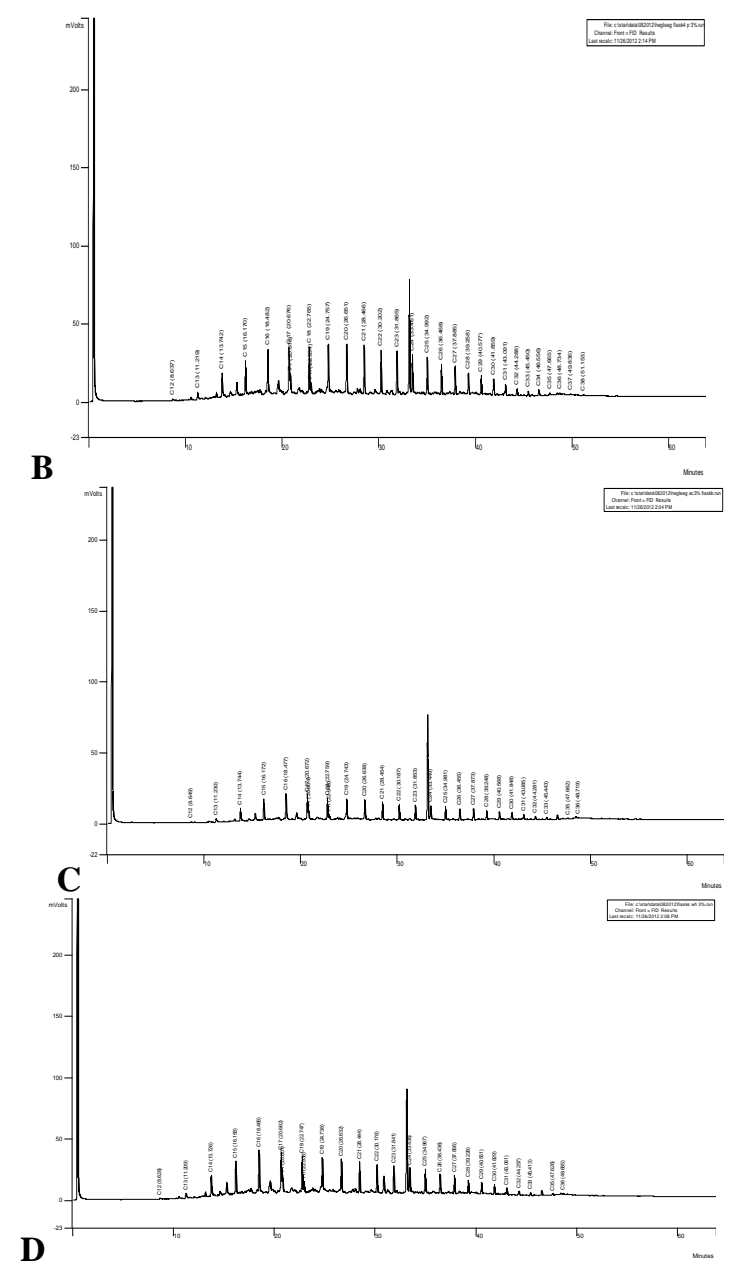

Fig.5 Chromatogram of TPH degradation of Heglig crude oil by HP +NPK (A), HAC+NPK (B) and $\mathrm{HWH}+\mathrm{NPK}(\mathrm{C})$ after 3 months

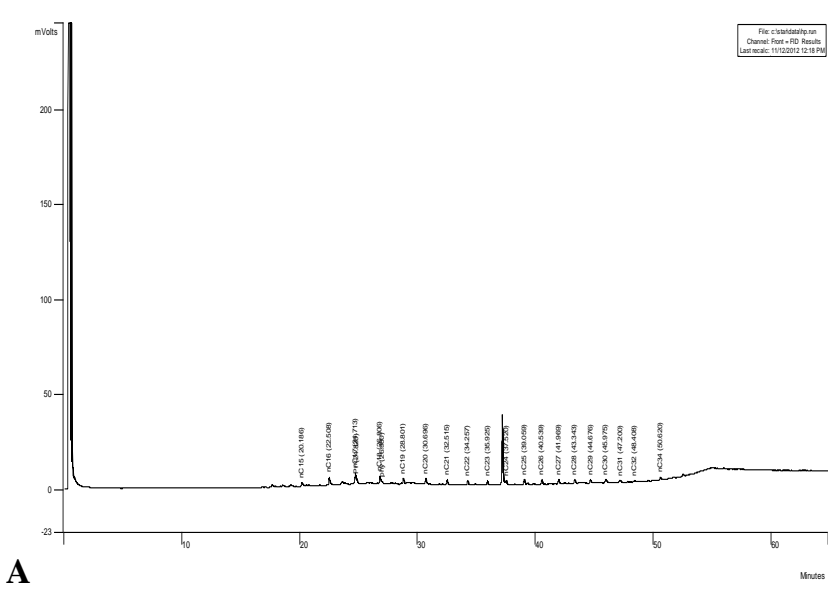



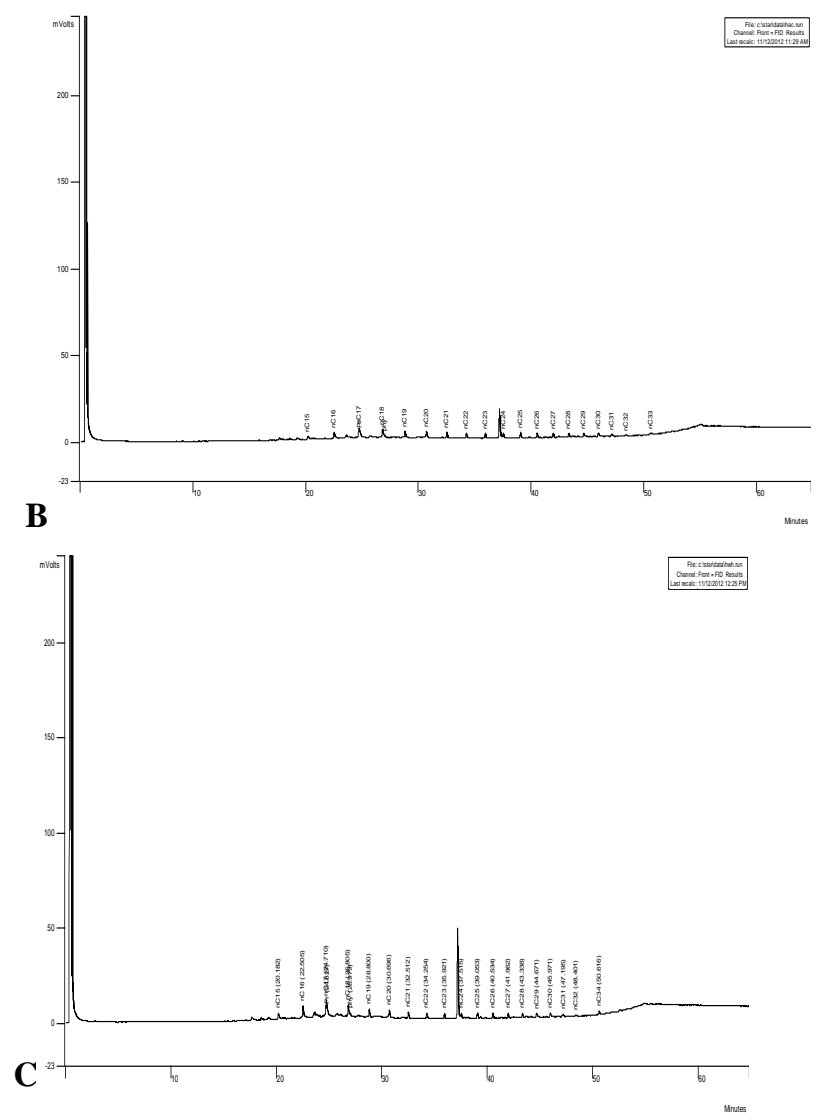

Malik and Ahmed (2012) reported that after 24 days of incubation the highest abiotic removal for lower alkanes (C13-C18) and higher alkanes (C21, C24 and C28) was 56 to $60 \%$, respectively.

However, middle alkanes reported to have a lower level of degradation such as $51 \%$ for C16 and 40\% forC17. The disappearance of significant quantities of short chain nalkanes (C8-C11) during the experiment and the decrease of total hydrocarbons (aliphatic and aromatics) could also be related to abiotic factors, such as evaporation and dispersion as explained by Luziet al. (2006).

In conclusion, all isolates were capable of degrading crude oil. The biodegradation percentages have gradually decreased with increasing concentration of crude oil. The study also presented that inorganic fertilizer containing nitrogen; phosphorus and potassium have great potentials in stimulating oil biodegradation in soil polluted with petroleum hydrocarbons.

\section{Acknowledgments}

The authors are grateful to Environment, Natural Resources and Desertification Research Institute, National Centre for Research for laboratory facilities. Thanks are also due to Petroleum Central Laboratory for Heglig crude oil analysis.

\section{References}

Adebusoye, S. A.; Ilori, M. O.; Amund,O. O.; Teniola, O. D and Olatope, S. O. 2007. Microbial degradation of petroleum hydrocarbons in a polluted tropical stream. World J. Microbiol. Biotechno., 23:1149-1159.

Abdualdaim M. M.; Aidil A. H.;Ainon H. and Wan Mohtat M. W. 2008. Development of three consortium for 
the bioremediation of crude petroleum-oil in contaminated water. Biological science 8 (4): 73-79.

Ainon H.; Amir, R.; Raja, F.; Hanim, R. A., and Noor, A. Y. 2010.Isolation and Characterization of Bacteria Degrading Sumandak and South Angsi Oils. Sains Malaysiana. 39(2): 161168.

American Petroleum Institute. (1986).The role of chemical dispersants on oil spills control. API publication 4425 . Washington DC.

Atlas, R. M.; and Bartha, R. 2006."Fate and effects of polluting petroleum in the marine environment". Residue Rev.,49 (1) :49-83.

Ayotamuno, M. J.;Kogbara, R. B.;Ogaj, S.O. T.; and Probert, S. D. 2006.Bioremidiation of a crude-oil polluted agricultural-soil at Port Harcourt, Nigeria. Applied energy, 83: 1249-1257.

Barathi, S. and Vasudevan, N. 2001.Utilization of petroleum hydrocarbons by Pseudomonas fluorescens isolated from a petroleumcontaminated soil. Enviro.Interna., 26 (5-6): Pp. 413-416.

Carmichae, L. M. and Pfaender, F. K. 1997.The effect of inorganic and organic supplements on the microbial degradation of phenanthrene and pyrene in soils.Biodegradation, 8 (1): $1-13$.

Cha^ıneau, C. H.; Rougeux, G.;Y'epr'emian, C. and Oudot, J. 2005.Effects of nutrient concentration on the biodegradation of crude oil and associated microbial populations in the soil. Soil Biol. and Bioch., 37 (8): 1490-1497.

Chaerun, S. K.; Tazaki, K.; Asada, R. and Kogure, K. 2004. Interaction between clay minerals and hydrocarbonutilizing indigenous microorganisms in high concentrations of heavy oil: implications for bioremediation. Enviro.Interna., 130: 911-922.

Cooney, J. J. 1984. The fate of petroleum pollutants in fresh water ecosystems.Petro.Microbio., Atlas, R. M. (ed.) Macmillan, New York, NY, USA. Pp. 399-434.

Evans, F. F.; Rosado, A. S.; Sebastian, G. V.; Casella, R.; Machado P. L. O. A. and Holmstr"om. C. 2004. Impact of oil contamination and biostimulation on the diversity of indigenous bacterial communities in soil. FEMS Microbio. Ecol., 49(2): 295-305.

Hollender, J.; Althoff, K.; Mundt, M. and Dott, W. 2003.Assessing the microbial activity of soil samples, its nutrient limitation and toxic effects of contaminants using a simple respiration test.Chemosphere, 53(3): 269-275.

Ijah, U. J. J and Antai, S. P. 2003. Removal of Nigerian light crude oil in soil over a 12-month period. Int. Biodeter. Biodegrad. 51: 93-99.

Ijah, U. J. J. and Antai, S. P. (b) 2003.The potential use of chicken-drop microorganisms for oil spill remediation. Enviro., 23(1): Pp. 89-95.

Ijah, U. J. J. and Ukpe, L.I. (a) 1992. Biodegradation of crude Oil by Bacillus strains 28A and 61B isolated from oil spilled soil. Waste Manag., 123: 55-60.

Lauretto R. C., Farias M. S., Bicego E. W. C., Taniguchi M. CMontone, S. and Pellizari, V. H. 2006. Potential for bioremediation of hydrocarbon polluted soils in the Maritime Antarctic. Sci. 18: 335-343.

Leahy, J.G.; Colwell, R.R. 1990.Microbial Degradation of hydrocarbons in the environment. Microbial Reviews,53 (3): 305-315.

Lin Q.; Mendelsson I. A.; Henry C. B.; 
Roberts P. O.; Walsh M. M.; Overton E. B. and PortierR..J. 1999.Effects of bioremediation agents on oil degradation in mineral and sandy salt marsh sediments. Environmental Technology, 20: 825-837.

Luzi AP, Ciapina EMP, Gamba.

Malik, Z. A. and Ahmed, A.2012. Degradation of petroleum hydrocarbons by oil isolated bacterial consortium. Afri.J. of Biotech.Vol. 11(3): pp. 650-658.

Margesin, R.; Labbe, D.; Schinner, F.; Greer, C.W. and Whyte, L. G. 2003. Characterization of hydrocarbon degrading microbial populations in contaminated and pristine Alpine soils. Appl.Environ. Microbiol. 69: 3085309.

Nyyssonen, M.,Kapanen, A.,Piskonen, R.,Lukkari, T.,Itavaara M. 2009. Function genes reveal the intrinsic $\mathrm{PAH}$ biodegradation potential in creosote-contaminated groundwater following in situ biostimulation. Ap. Micro and biotech. 84 (1):169-182.

Oliver, B. andMagot, M. 2005. Indigenous microbial communities in oil fields.In Petroleum Microbiol, Washington, DC: ASM Press, pp. 21-34.

Pelletier, E.; Delille, D. and Delille B. 2004. Crude oil bioremediation in subAntarctic intertidal sediments: chemistry and toxicity of oiled residues Mari. Environ. Resea., 57 (4): 311-327.

Rahman, K. S. M.; Rahman, J. T.; Kourkoutas, Y.; Petsas, I.; Marchant, R. and Banat, I. M. 2003. Enhanced bioremediation of n-alkane in petroleum sludge using bacterial consortium amended with rhamnolipid and micronutrients. Bioreso. Technol., 90 (2): Pp. 159-168.

Rahman, K. S. M.; Rahman, J. T.; Lakshmanaperumalsamy, P. and Banat, I. M. 2002.Towards efficient crude oil degradation by a mixed bacterial consortium.Bioresour. Technol. 85: 257-261.

Ryan, J., George, E. and Abdul, R.. 2001. Soil and plant analysis laboratory manual. 2 ed. Jointly published by the International Center for Agricultural Research in the Dry Areas (ICARDA) and the National Agricultural Research Center (NARC).

Sang-Hwan, 1.;Seokho, 1.; DaeYaeon, k. andjeong- gyu, k. 2007.Degradation characteristics of waste lubricants under different nutrient condition.J. hazard.mater., 143: 65-72.

Vasudevan, N. and Rajaram, P. (2001). Bioremediation of oil sludge contaminated soil. Environ. Int. 26: 409-411.

Walter, M., Boyd-Wilson, K.S.H., McNaughton, D., Northcott, G., 2005."Laboratory trials on the bioremediation of aged pentachlorophenol residues".J.Int. Biodeter\&Biodegr. 55(3):121-130.

Zajic, J. E. and Supplisson, B. 1972. Emulsification and degradation of "Bunker C" fuel oil by microorganisms. Biotech and Bioengin., 14 (3):. 331-343.

\section{How to cite this article:}

Maha AbelHafeez Mohamed, AwadGalal Osman, Adil Ali Elhussein, Somaya Sirelkhatim Mohamed and Ahmed Ali Mahdi. 2016. The Potential Use of NPK and Bacterial Isolates to Degrade Heglig crude Oil in Sudan. Int.J.Curr.Microbiol.App.Sci. 5(10): 825-835. doi: http://dx.doi.org/10.20546/ijcmas.2016.510.090 